\title{
Mental and Practical Roots of the Formation of Democratic Party of Iran and Its Ruling Thought
}

\author{
Mohammad Ali Ahmadi ${ }^{1}$ \\ ${ }^{1}$ Department of Political Science, Faculty of Law and Political Science, University of Tehran, Tehran, Iran \\ Correspondence: Mohammad Ali Ahmadi, Department of Political Science, Faculty of Law and Political Science, \\ University of Tehran, Tehran, Iran.
}

Received: April 28, 2016 Accepted: May 25, 2016 Online Published: June 29, 2016

doi:10.5539/jpl.v9n5p132 URL: http://dx.doi.org/10.5539/jpl.v9n5p132

\begin{abstract}
By the establishment of branches of $<$ EJTEMAIYUNAMIYUN $>$ and the activation of Armenian Democratic social groups, new political currents inspired from socialist thoughts entered the political scene of Iran. This current before the formation of second national counsel parliament was active under different groups and categories. The establishment of new political system after the victory of constitutionalists over minor tyranny and conquering Tehran some of the activists of these organizations were persuaded to engage at parliamentary activities. Change of the election law at the threshold of second parliament establishment which abolished the union representativeness principle facilitated the possibility of party activities in parliament therefore by the occurrence of the new conditions the activities of these groups were oriented to direct influence and attendance in the power structure by the party. With this goal in mind, some of the EJTEMAIYUN and a number of active Armenian social democrats of Tabriz with the assistance of Rasulzade, socialist $<$ Hemmat organization $>$, founded $<$ Democratic Party of Iran $>$. The present study is an attempt to analyze the bases which lead to the cooperation of these people with various political and organizational origins. The practical actions of the organizers by direct extraction from documents related to Democrat Party and the extraction of the ruling thought from the published texts by this organization constitute the content of the present article.
\end{abstract}

Keywords: social democracy, democratic party of Iran, revolutionary category, EJTEMAIYUNAMIYUN, social democratic group of Tabriz, Hemmat organization, EJTEMAIYUNETEDALIYUN, IRANE-NO

\section{Introduction}

Democratic Party of Iran started its activities as one of the parties of national council parliament. In the second parliament two main parties <Democrat Iran $>$ and $<$ EJTEMAIYUNETEDALIYUN $>$ were present along with smaller parties such as <ETTEFAGH\&TARAGGI party $>$. According to MalakoshoaraBahar $<$ Democrat Party $>$ was considered as revolutionary and the ETEDALIYUN party was considered as moderate (Bahar, 2009, 8). Some called the Democrat party as ENGELABIYUN or the revolutionary group and some historic texts have referred to them with the same title. Taghizade one of the founders of the Democrat party in Iran believes that this party was named ENGELABIYUN although they denied this title and did not approve it but thanks to the repetition and the advertisement it has remained in the minds of the public and even in some of the historic books of the constitutionalist era it has been repeated as a certain fact. (Taghizade, 1967, 116) He thoroughly expresses his dissatisfaction of this nomination in an essay entitled $<$ KASHFOLGETA $>$ and claims that this title is put on us by ETEDALIYUN so that call them moderate and by warning against the extremist thoughts and attract more people to them. (HABLOLMATIN 13 SAFAR, 1960, 19)

Democrat Party in the second parliament was in minority. In this period of the parliament Democrats emphasized on their responsibility as a minority group in a parliamentary group that is criticism of the majority and the emerging cabinet from it. (Central committee resolution RABIOALSANI 1960) Democrat Party expanded its branches across Iran and did not limit its activities just to parliament and Capital. Seyyed Hassan TaghiZade, WeramPilusiantz ${ }^{*}$ TigranDerwish ${ }^{* *}$ (Terhakupian), Muhammad Amin Rasulzade, Heidar Khan Amuogli, HossienGoliKhanNavvab, Hakimollmaleke, SoleimanMirzaEskandari, Seyyed Reza Mosavat, HossienParviz, Ali Muhammad Muhammad Ali Tarbiyat were the main organizers of the party. Democrat party official organ was the $<$ IRANE-NO $>$ paper which was published in Tehran. They also published $<$ SHAFAGH $>$ in Tabriz and $<$ NOBAHAR $>$ in Khorasan(spring, 2009, 9). 


\section{Founders}

Before the start of second parliament elections some of the social democrat activists took the required measures to establish parliamentary party to represent their thoughts in and out of the parliament. But the combination of those who had a role in organizing and founding Democrat Party showed the cooperation of individuals with various organizational and political backgrounds in this framework. Taghizade migrated to London after the bombardment of the parliament. He moved to Caucasus and from there to Tabriz and then back to Tehran and before the elections began his attempts to organize the party. The letters written by Pilusian and Terhakupian to him shows that the works related to the establishment of the temporary central committee in Tehran was handled by him. (Afshar, 1970, 238-322) these letters containing several explanations about the way of establishment and activities of this party reflect the continual cooperation of Armenian social democrats that is Pilusian and Terhakupian. Rasulzade in 1909 returned to Iran and cooperated in the preparation of code of conduct and system and determining the policy of the Democratic Party and was responsible for the editorial post of the IRANE-NO paper. (Raisniaya 2008,9) The combination of these people and people such as Heidar Khan, Mosavat, Hakimolmalek, Tarbiyat, Hosingolikhannavvab, etc that on the basis of the credible historic texts and documents had a role in the organizationof democratic party of Iran the trace of EJTEMAIYUNAMIYUN activists Tabriz social democrat party and Hemmat organization show their role in the establishment of it.

The first establishment of EJTEMAIYUNAMIYUN was founded in Baku in 1905. From the late $19^{\text {th }}$ century a large number of the economic forces who had lost their jobs under the influence of the immethodical foreign capital into Iran were forced to immigrate to Transcaucasia. (Issawi, 1971, 52) in the final decades of this century and following the activation of industries in Transcaucasia this region became one of the industrial poles of the Russia. (Trotsky, 1973, 36) The development of industry especially in Baku and the lack of the ability of the economy of Iran to attract the damaged work force in other sectors of the economy were the most important factors of the immigration of Iranians to this region ${ }^{1}$. The immigrations increased from the beginning of the twentieth century and Iranian immigrants constituted a large number of the residents of Transcaucasia. (Arutunian, 2006,30) At the same time social democrat organizations were the most significant active political forces of the region. Iranians in particular were under the influence of the Hemmat organizational propaganda which was constituted from the Muslim socialists. Iranian immigrants with the assistance of some of the members of the Hemmat founded the first organization of the social democrat party of Iran that is EJTEMAIYUNAMIYUN in Baku. EJTEMAIYUN expanded their activities into Iran and established branches in Tehran, Tabriz, Mashhad, Isfahan, and Rasht. (Mojahedin organization statute, n.d) As it can be inferred from the memories of Heidar khan the Tehran branch of EJTEMAIYUNAMIYUN was established by him. (Yadegar, 1946, 70) Taghizade who was the representative of the first national council had cooperation with Tehran branch of EJTEMAIYUN. (Adamiyat, 2009, 20) In addition to that his like-minded individuals in the (national revolution committee) that isHakimolmalek, Seyyed Reza Mosavat, HossiengoliNavvab, and HossienParviz had association with EJTEMAIYUN. (RezazadeMalekn.d., 41-43). Tarbiyat was also one of the active members of the Tabriz branch of this organization (Ebrahimof, 1981,67) and his brother Ali mohammad khan was active in relation with this branch and the other branch of the EJTEMAIYUN in Rasht. (NasimeShomal, 24 ${ }^{\text {th }}$ of Muharram 1948, 2)

But Pilusian and Terhakupianhad a different organizational origin. These two in the past were considered as the members of the social democrat group of Tabriz. In the late years of the nineteenth century the political activists of Armenia in order to support the minority of Armenians in Russia and Ottoman established two parties of Henchak and Dashnak. These parties were socialist in terms of ideology and in terms of method revolutionary. Both parties tried for the independence of different parts of the Armenia from the dominance of Russia and Ottoman and establishing an independent country (Kazemzadeh, 1951, 9). And (unanimous, 1981, 10) Hechak and dashnak s found Iran a secure place to support their revolutionaries. They prepared arms and ammunition in Northern cities of Iran and then sent them to the border regions to equip their fighters. (Padmagriyn, 1973, 282). The activists of these parties at the time of their activities in Iran theyr started spreading their thoughts and beliefs among Iranian Armenians and then Non Armenians ${ }^{2}$. In this line some of them arranged a group in Tabriz and started some activities. This group started its activities before September 1905 by the purpose of discussion over the social democrat thought (Karkhanian to Polkhanof, September 1905) At least from 1908 people such as ArshavirchalangariyanViramPilusian, Vasokhachaturian and Terhakupian were members of the Tabriz group. These people were in communication with socialist leaders in Europe such as Polkhanof and Kaoteski and communicated their theoretical problems and arguments with them (Khosropanah, 2009, 77-115). Rasulzade was also considered as a member of the Hemmat organization. It was an organization, which was active in Transcaucasia and had a close cooperation with Baku committee of the Russian labor democrat social party. 
Hemmat was established by the innovation of a number of Azari Muslim intellectuals for advertisement activities among Muslims in Baku in 1904. (Shakeri, 2005, 175) Swietochowski ${ }^{*}$ considers the appearance of Hemmat as the result of the disregard of Russian labor social democrat party committee of Baku to the necessity of advertisement among the Muslims. In his opinion this negligence led some of the normal members of this party to make their firs individual attempts to familiarize women with socialist thoughts and hence establish Hemmat ${ }^{3}$. (Swietochowski, 2002,63) this is the same narration in which Afendif emphasizes on the founders of this organization. (Ravasani, 1984, 57) They first established an intellectual hub in 1903 and the next year they started their advertisement activities among Muslims. In this group M.G. Masumof, SoltanMajidAfandif, AsadollahAkhundof, Muhammad Amin Rasulzade, Muhammad Hassan Hajinski and Abbas KazemZadewere members and the first three one were the members of Russian labor social democrat party. In the early 1905 Mashhadi Aziz Begof and NarimanNarimanof also joined this group and became part of the leaders of the party. (Swietochowski, 2002, 64) Hemat expended its branches to other cities of Transcaucasia very soon and managed to attract a large number of the Muslim community of the region who were mostly Iranian to the membership of this party. Most of the members of the Hemmat were oil workers and one fourth of them had Iranian biography. (Yaghikian, 2007,365). Narimanof who was considered as one of the leaders of the Hemmathad a significant role in the establishment of EJTEMAIYUNAMIYUN and took its leadership ${ }^{4}$. Rasulzade after the suppression of Hemmat during Stolipin ${ }^{*}$ and the arrest of some of the leaders took asylum in Iran in 1909. (Afanasian, 1991,13)

\section{Intellectual Substrate}

But what happened that these people with such origins cooperated with each other and concluded that proceed with their activities within democrat party? It seems that some of the leaders of EJTEMAIYUNAMIYUN decided to make changes in their way and type their activities. They could abandon their secret fighting method and follow a new path and proceed with open party activities. The new conditions which had happened in the country provided them with such possibility. The new conditions provided them with this opportunity to follow their activities with more efficiency and power and actualize their thoughts. Change of the election law was among the significant reason in this respect since it attracted them towards parliamentary activities. From this respect by the elimination of hierarchical base of elections provide a better substrate for sending its forces via party to the parliament. The interesting point is that EJTEMAIYUNbefore the manifesto passed in Mashhad in addition to emphasis on unsparing support of the parliament called for the cancellation of the representative class selections (Mojahedin community manifesto 1907, article 4) and may have made attempts to cancel this law among the decision makers. <Tabriz association>was considered as one of the most influential channels on decision making in this respect. This association which was selected as the representative of the rest of the associations for the active role of it during the minor tyranny started negotiations with the government in terms of the codification of new law ${ }^{5}$. (Rafiee, 1983, 73) Tabriz EJTEMAIYUNhad a significant role in Tabriz association and in some cases affected their performance type (Afari, 2000,122) Therefore, given the influence of EJTEMAIYUNin this association this possibility was reinforced that they actualize their demands by this means. In new election rules the number of the Tabriz representatives which was one of the main centers of activities of EJTEMAIYUNhad increased from 12 to 20. (Parliament election law, 1950, first chapter article 2) on the other hand the political system of the country was military parliamentary and consequently on the basis of the constitution parliament had a significant role in the power structure. Therefore, given the possibilities provided by the new election law and also the significance of the parliament there was a possibility that by more political force and in a more influential way enter the power structure and EJTEMAIYUNby the leadership of Tagizade started their attempts in this respect.

YahyaDolatAbadi writes in this respect:

$<$ The gentlemen [Taghizade et al ] introduce some of their friends in particular the provinces of Tabriz to people in Tehran for the parliament representativeness to be able to win the majority of the parliament and do their best in this respect> (DolatAbadi, 1983, 120).

Hence some of the activists of EJTEMAIYUNconcluded that at the present time there is a possibility of more colorful presence in the parliament and can influence the power structure by this means and should not lose the opportunity and for the same reason attended the parliament and for powerful attendance at parliament they had o organize their forces in a parliamentary party by the start of the election but now that they have decided to this end they had to show their separation of their background and prove that they have selected a different way from that of EJTEMAIYUNAMIYUN. The title EJTEMAIYUNI which had concluded that was put forward in the framework of democrat party. Some of them were among those main activists $t$ finalize this party. Tagizade, Heidar khan, Mosavat, Hakimolmalek, etc. They cut their nexus with EJTEMAIYUNAMIYUN of Caucasia. The type of the performance of Tagizade and his followers was not in accord with the view of the center of the creed 
in Caucasia for the same reason some representative came to Tehran to express their protest for this type of performance. (ibid, 121) Apparently they did not want to act under the supervision and in relationship with the Caucasia center and intended to act independently. May be this lead the EJTEMAIYUNAMIYUN to cloze its branches across Iran. Some of the members of this sect in Iran were killed during the bombardment of parliament and some joined the democrat party and other parties. Thes factors along with disobedience of the center caused the center of the sect in Caucasia besides issuing a penalty order announces the detention of its branches in Iran $^{6}$. (Penalty order of EJTEMAIYUNAMIYUN January 1910)

Two of the Armenian social democrats of Tabriz group that is Pilusian and terhakupian are the other founder groups of democrat party of Iran. Their juxtaposition next to other founders of various organizations originates from their ruling ideological intellect. Tabriz group has a special attention to the interpretation of Iran's condition under the Marxist ideology framework and this fact lead to intellectual differences among the members in the face of the establishment of revolutionary conditions. The group's dispute was over the attendance at the constitutionalist movement which originated from their inferences from the identity of the revolution of Iran. (Chalangarian to Kaotski, January 1908) they also had disputes over the selection of organizational tactics. The majority of the members believed that Iran has entered the stage of producing capitalism and industrial production (factories of tobacco, china pipe, steam mill, and willows etc) have been started next to large manual workshops. And the presence of the proletariat class next to the small industrialists prepared the required basis for the socialist activities. They believed that they should form a pure social democrat group and organize the workers and advertise socialism. (Tabriz group meeting, October 1908)

In contrast Pilusian and Terhakupian believed that capitalism and proletariat in Iran is at the fetus level. Iran although has just started the path of capitalism but it is not at the stage of industrialism and therefore the modern proletariat has not appeared. In case they exist there is no substrate for social democrat activities and would not lead to positive outcomes because the objective and mental condition of it has not become prepared to be able to actualize the unity of the labor party. (ibid) They believed that in Iran production is done in the form of medieval centuries and the weak proletariat and landless farmers there is no required conditions for the proletariat fight therefore, the temporary tactic of the group should be organizing the democratic elements against the feudalism and tyranny. In their vantage point they should follow Marx and Agels in 1848 and the forces should become united temporarily under the democracy flag and always move it towards the left party for the expansive public power. (Terhakupian to Polkhanof, December 1908) accordingly Pilusian and Terhakupian in the condition of Iran in those days not only did not consider the socialist activities efficient and practical but they considered it with negative impacts. Under the framework of their ideology and on the basis of their assumption of the conditions of those days of Iran they believed in democratic activities and for the same reason it was quite natural that they tried to establish a party in this framework and accompany Tagizade and others who were in the same path at that time.

Rsulzade also believed similarly and on the basis of his actions and thoughts he considered democratic activities apposite for the ruling conditions of Iranian society. He believed that as far as there isn't European and American capitalism in Iran to become socialist and fight against it and since there is no capital and capitalism there is no proletariat therefore, it is impossible to think of the dominance of a non-existence guild. In his opinion in a place where there is a remainder of feudalism the history has showed us that the socialists are the same as Bougeois have fought against it because to facilitate the apposite substrate for the socialist advertisement the dominance of capitalism is among the requirements. In his opinion in a country where there is neither capitalism nor proletariat and people earn living through medieval century method in a country like Iran socialism is an unreal dream. (Rasulzade, 1949, 26-27) Therefore, the thoughts of all these people came together at one point and made their cooperation for the establishment of democrat party.

\section{Practical Measures}

The ruling conditions at that time made founders organize the party as soon as possible. Elections were soon on the way and Tagizade and his followers had prioritized the action in parliament as the first priority of their goals and need to hurry in organizing the party so that facilitate the expansive attendance of their representatives in the parliament. The country's atmosphere after conquering Tehran was full of disputes and competitions between constitutionalist groups. The constitutionalist fighters were divided into two groups and were struggling deeply over different issues. On the one hand Tagizade and his followers and on the other hand people such as Maazosaltane, Mirza Ali Muhammad Vazirzade, AsadollahKordestani, Mirza Muhammad SadegTabatabie etc. (DolatAbadi, 1983, 119-120) Both group given the significance of the parliament in the political system of the country actively tried to outshine the rivals by obtaining the majority of the parliament. The sides did not prevent them from taking any action to obtain more power. (Shuster, 1913, 212) The presence of such an atmosphere 
even made Kasravi to have a different vantage point in his history writing and present a different view of the formation of the democrat party. He believes that the origin of democrat party formation is the result of separation in between ENGELABIYUN rather than being affected by professional and mental measures. As it can be inferred from his writing the classification of constitutionalists and the revolutionary group of Tagizade or the very democrat party is one part of the classification and ETEDALIYUN is the other part is not a natural process but it is a party establishment to follow a definite political policy. (Kasravi, 1999,127) But although gap was not insignificant in this case the programs of the democrat party shows that the establishment of this party has been quite purposeful and on the basis of special political policy.

The first action taken by Taghizade and like-minded people for the organization of the party was the establishment of a temporary and central committee for the codification of a temporary code of principle and conduct. On the basis of the ten months activity report of the temporary center this committee was established in the early SHAVVAL of 1948 (late September 1909). (ten months activity report m.m.n.d.) Second national parliament was established early ZIGADE of the same year, (official paper 1946,6) Therefore, the temporary center of the party was established within a month before the establishment of the parliament and tried to arrange the temporary code of principles and conduct. The founders had decided in the first place to do all activities related to party organization for a period of time. In the ten months report of the activities of the temporary center the reason of this secrecy is explained as follows:

$<$ because of the ethical corruption of the capital and the rigging by the enemies of the freedom that make use of all illegal and accusations to destroy the base of any sacred action and out of personal intentions do not allow a political sect provide the nations' happiness in accord with an apposite program under an orderly organization the temporary center for a period of time by considering the experiences and the observation of the people's ethic and the obstacles ahead of the goals of development in Iran and particularly Tehran for some time it is expedient to keep the sect and the program under secrecy and after the growth of this new sapling and by the fulfillment of the openness requirements expand this political party via various tools of speech and writing in Iran.> (ten months activity report m.m.)

The temporary code of principles was similarly codified. This code of principles emphasized on the type of establishment of circles and areas <the number of the sect in Tehran before reaching to 100 persons including ten areas with the exception of the temporary center members for no reason the name or feature and the superficial characteristics of the sect should not appear and the establishment of the sect would not be announced $>$ and until this condition is not fulfilled the members $<$ have to hide the path and activities and any signs and refrain from any type of publication>. And similarly it was stated that unless the number of the party members $<$ reach the aforesaid number official sign for the papers is not necessary $>$. (temporary code of principles, n.d.) This secrecy kept the code of principles and conduct out of the sight of the public for a period of time. But this secrecy was a short-term tactic because it was decided that after the provision of the required facilities these activities become open and after a year it became likewise.

The founders were even sensitive about the name of the party. They had called their organization $<$ democrat $>$ but on the basis of the assumption of the current conditions they were doubtful in terms of the use of the tile in future and at the time of public activities and therefore they decided to make use of a term closer in Persian. Pilusian emphasized that Iranians do not have an apposite reaction to the foreign and unfamiliar terms (Pilusian to Taghizade, February 1910) Therefore, a Persian term had to be selected for the nomination of the party so that first of all reflect the type of its approach and secondly and does not provide the excuses for the opposites.

In terms of the selection of the title <democrat $>$ for the party it can be explained that on the basis of what was rationalized both the Armenian social democrats were interested in showing the differences of their political policy with the majority of the group and former EJTEMAIYUN and EJTEMAIYUNAMIYUN.

The importance of this issue for the minority Tabriz group is clear in Pilusian's letter to Taghizade. When he asks for a Persian equivalent for the <democrat $>$ he refers to one of the reasons of this request and his concern in relation to our discussion was that this term might be confused with $<$ social democrat $>$. (ibid) On the other hand use of the word could be used an excuse by the opposites to oppose. Malekzade writes in this respect that:

$<$ the outlook of the democrat party was adapted from the outlook of social democrat but since at that time social outlook had not developed and become universal and people were afraid o its name and considered the name social as revolutionary and common and inevitably the leaders of the party refrained from using the name social democrat and just applied the term democrat> (Malekzade, 1984, 1949). Ultimately the term AMIYUN which was the Persian translation of democrat was selected but the party at the time of open activities mostly made use of the term $<$ democrat $>$ to refer to itself and was mostly referred to by this name rather than the Persian title. 
This party in some cases call itself $<$ Democrat party of Iran, AMIYUN. (democrat sect code of conduct, 1949, on the cover). Temporary central committee from the middle Dhu al-Hijjah that is around two and a half months after the start of activities in addition to facilitating the requirements of establishing branches and headquarters on the basis of the temporary principle contents started recruitment in Tehran. This temporary committee was able to recruit 135 people in this city after three months and a half after this date. (ten months activity report of the party m.m.) In line with these activities the parliamentary fraction of the party was active in the parliament without displaying their organizational identity. In order to establish headquarters and branches in provinces and towns of other cities the leaders of the democrat party also emphasized on the spread of their code of conduct across other regions apart from Tehran. The code of conduct of the party was privately advertised in Tabriz, Qazvin, Qom, Isfahan, Hamedan, Kermanshah, Mashhad, and some other cities for recruitment. Similarly the thoughts of the democrat party via IRANE-NO in an unofficial way and by the use of Caucasus press (in Turkish) were published. By the expansion of the party organization in Tehran and other cities finally the temporary center of the organization because of the fulfillment of the requirements and demands of the branched that were continually sent decided to make the party activities public therefore, tried to <make a temporary center legally to selective.>(ibid) For the selection of the central and the type of the public activities of the party a new code of principles was prepared and arranged and issues such as the establishment of the branches, local committees, provincial committees, central committee, local parliaments, provincial conference, general congress, parliamentary branch and the type of member selection were predicted in it. On the basis of this statute the members of the provincial and local committees after the election in provincial conference and local congresses send their representatives for the selection of central committee selection to the general congress. The members of the central committee were selected for a year and $<$ within the authority $>$ were allowed to $<$ with left wing political sects $>$ and committees that did not hold negating views against the party hold talks and negotiations and make alliances ${ }^{7}$. The stature insisted on the fact that the party at state establishments and elections should make use of all of its power to support the related party candidates (democrat sect statute, 1949, 18).

By the codification of the new statute the central election features were determined and afterwards the related measures were taken to establish it. Irane-no paper on $20^{\text {th }}$ of Shavval 1949 reported of an election in one of the five branches of Tehran. (Irane-no, the aforementioned date, 3) This paper after some time on $11^{\text {th }}$ of Zelgade announced that the elections of the other four branches have been administered and the local committee of Tehran has been established ( $5^{\text {th }}$ of December 1910) then the private resolution of the party to the surrounding committees which was announced in the same year the establishment of the first central committee was announced (central committee resolution, aforesaid date) therefore, the selected committee had existed just before this date. The first public activity of this committee was the announcement of a statement by its signature on $5^{\text {th }}$ of Zillhaje in Irane-no paper (Irane-no, afpresaid date, 1-2)

\section{Party Press}

In addition to the emphasis on the spread of the party thoughts by the members among democrats, $<$ Irane-no $>$ paper was the principle hub of spreading the outlook of Democratic Party. Irane-no in 1949 officially became the organ of this organization. HosseinParviz who followed the assignment of this paper by Abuzia to this party in a letter on $18^{\text {th }}$ of Sahavval 1949 to Taghizade besides reporting the large amount of money requested by him and that he is not still complacent he wrote that, Irane-no paper <you are supposed to come out $>$ (Parviz to Tagizade, aforementioned date). Abuzia was the concessionaire of Irane-no and before this paper he used to publish the Mjahed paper the organ of EJTEMAIYUNAMIYUN in Tabriz ${ }^{8}$. Hence the first number of Irane-no as the official organ of democrat party of Iran with the managing director of Seyyed Mahdi Afjei and the editorial of Rasulzade on $19^{\text {th }}$ of Shavval 1949 (22 $2^{\text {nd }}$ of October 1910) was published ${ }^{9}$. But as it was mentioned earlier this paper before the official assignment was also under the control of the democrat party because the ten months activity report of the temporary center which was established in Shavval1948 has openly referred to the activities of the paper in spreading the thoughts of the party over this time. Rasulzade had the main role in the publication of the Irane-no paper. He provided the democrat party organ with his press and theoretic experiences that had learned in Caucasus ${ }^{10}$. Irane-no quickly became the number one paper of Tehran (Abrahimian, 1998, 130) Rasulzade in his report to the Taraggi paper wrote that it would be he first paper in size, form and the primary program of the paper. (Rasulzade, 2008, 303) Edvard Brown also writes about Irane-no that this paper is the first and one of the best papers in the history of Iranian press which has been published in the history of Iran press. (Brown, 1910, 243) He has asserted somewhere else that this paper has entered the type of European journalism into Iran and became the pattern of the other papers. (Brown, 1914, 52)

The publication of Irane-no stared in 1948. This paper from the time it started spreading the outlook of democrat party in an unofficial way was under the pressure and was finally confiscated. The renewed publication of the 
Irane-no was at the time of its assignment to the democrat party. Rasulzade who had the editorial of the paper at this time under the pressure of the Tsarist state was exiled from Tehran. Irane-no after the exit of Rasulzade was published until it was confiscated by the government. The renewed publication of this paper did not last long and by the closure of the Parliament was closed again. (ibid, 52-53) The parliament was closed as a result of the Russian ultimatum on the dismissal of the counselor Shuster by the government and Nayeboal saltine. The government exiled those opposing this dismissal and scattered them and confiscated their press in Tehran and other areas. Democrats in addition to the papers $<$ Irane-no $>$, $<$ Shafag $>$, and $<$ Nobahar $>$ which were respectively published in Tehran, Tabriz and Mashhad they also published $<$ Qazvin $>$ in Qazvin, <Zayanderud $>$ in Isfahan $<$ SedayeGilan $>$ in Gilan and $<$ Farvardin $>$ in Orumieh. (union, 1982, 218) $<$ Nobahar $>$ paper was published under the management of MalakoshoarayeBahar but after the confiscation of the paper he was also exiled into Tehran. Bahar after the establishment of the third parliament published $<$ Nobahar $>$ instead of $<$ Irane-no $>$ as the democrat party organ in this city. By the start of the First World War this paper was also confiscated under the pressure of the Russian and English governments (Bahar, 2009, 17-23)

\section{Organizational Programs and the Ruling Thought of the Party}

Democrat party announced its organizational programs under codes of conduct, statements, resolution, and announcements openly to the public and privately via internal notices for the members. As we saw the theorists of the party under their ideological framework believed in class struggle to establish new political and economic system and therefore, considered the support of lower classes of society through legal methods and afterwards the fulfillment of democratic revolution via legal means as their main strategy. Accordingly they claimed their support of the excluded and condemned classes of the society in their organizational programs. They backed active participation in parliament and trying to establish democracy as the tactic to reach this goal (Irane-no $21^{\text {st }}$ of Shavval, 1949, 2) Leaders of the democrat party believed that this public is able to acquire excellent position in the social forces balance and secure and provide its interests which is the benefit of the majority and this would not be fulfilled unless a political party with regular establishments and activities by influential presence in the parliament save the interests of unions and classes (Parliamentary branch statement Safar, 1950) According to democrats the national government as the guard of weak class interests only under the shade of the establishment of political parties can have the possibility of existence because these classes can only under the special protection of respected parties could defend their rights (Irane-no $23^{\text {rd }}$ of Shavval1948, 1) In their opinion farmers and villagers and city shopkeepers although constitute the majority of this country but they lack the required material and spiritual power to instill their rights, determine their power co-ordinations, legislating law and make the legislators to observe their rights therefore, they need a power to provide their class interests (Parliamentary branch statement) Democrat party considered the provision of this power as its prophecy. Therefore, democrats by supporting the presence of parties at parliament hoped that within a party establishment can represent the weak class of the society in the parliament. (parliament negotiation $25^{\text {th }}$ of Safar, 1950) Accordingly, they considered their party as $<$ the toiler party of the society> (Nobahar, 23 ${ }^{\text {rd }}$ of Shavval, 1949, 2) in the resolution of this party which had been issued for determining their relations with cabinet it was stated:

$<$ The contrast between democrat party of Iran and the coalition committee is the same as the contrast between the grandee and the nobles and the tillers of the democracy. $>$ (Resolution, $9^{\text {th }}$ of Rabi alsani, 1950)

In line with this purpose in Democratic Party code of conduct at the top of the political goals the support of eligibility of constitutionalism and parliament had been emphasized. The fulfillment of democracy was traced in the equality of all individuals in the eyes of the law without discrimination of race, religion or nation, freedom of speech, press, communities, populations and the shut down (strikes), free and compulsory education for all and special attention to the education of women (democrat code of conduct 1949, 10-13) The economic program of the party was also directed to this goal. The cancelation of personal and union privileges, laying tax on additional income, confiscating state lands and using its income on humanitarian issues, nationalizing the jungles and plains, forbiddance of wok for under 18 year olds, limiting the working hour to 10 hours an assigning one day holiday to workers and dividing lands among the farmers (ibid, 13-15) Democrats on the basis of the importance that they allotted to economy they believed that the codification of regular economic program and trying to pass it in parliament was an influential factor in fulfilling the rights of the underprivileged. They announced their goals as eliminating the class privileges and equal benefit of all social classes on the basis of intrinsic talent and personal attempt of the facilities of the country (Irane-no $16^{\text {th }}$ of Rabiolaval 1950, 2).

The land policy of the party and the emphasis on the separation of religion from politics constituted the most radical part of the democratic programs. Democrat party in it code of conduct statement had requested the free provision of lands to the farmers and buying the master lands by agriculture bank and selling them to the farmers by providing facilities. (Democrat party code of conduct part 7 of article 17) the leaders of the party had a special 
attention to the land owning system correction (lord-vassal) and considered it as a significant tool of destroying feudalism in Iran. Before this and under the influence of social democrat outlook on the country intellectuals such as TalbofTabrizi the plan of the ownership of farmer on the land had been proposed (Talbof, 1925, 124). and had entered into the programs of EJTEMAIYUNAMIYUN ${ }^{11}$ (Mojahedin code of conduct, 1907, article 7) and (Baku program n.d article 1) but democrat party was trying to make it legal via parliament but was not faced with positive reaction (Parliamnet negotiations, $23^{\text {rd }}$ of Safar 1950) the inclusion of the separation of religion from politics among the goals of the democrat party had various feedbacks. Naturally as Tagizade states this was not in accord with the dominant situation of those days ${ }^{12}$. (Tagizade, 1957, 117) and placed the party in contrast and against the religion and the religious scholars but in the opinion of the democrats this part of the code of conduct of the party was (in accord with the equality spirit of Islam). Democratic principle textbook written by a democrat which has a religious justification about the programs of the party writes in this respect as follows:

$<$ we should know that all elements of the code of conduct and the goals of the democrat party which demands a public government for the toilers is based on a basis and principle upon whichthe sacred rules of Islam are founded that is the equality of the members of the nation in terms of rights and priority and not allotting privileges to anyone or any union over others because of wealth, dominance and observing the equality rights rules according to the statement that is an instance of this (a democrat, 1949, 11)

Democrat leaders in their internal notes made the members fully obedient both verbally and practically to observe and keep the religious beliefs requirements and rules $^{13}$. (internal resolution $30^{\text {th }}$ of Zilgade 1948) they believed in the single principles of religion and the elimination of superstitions of the belief (ibid).

The demands of the democrat party in terms of the country management were arranged two axes of internal and external policies. The internal policy of the party was founded on three principles of <centrality>, $<$ parliamentary $>$ and $<$ democracy $>$. Democrats believed that the reason that today the country is in a crisis is the lack of centrality and it is the result of previous years' behaviors and that of previous $<$ kings $>$ of Iran. They asserted that in the past because of the lack of centrality and the lack of relation between provinces and the center each province was considered as a country and every ruler had unlimited range of power that is they were the separate king of those provinces and for the same reason the king was called king of kings. They believed that the first priority of the management of a country is to establish a central power that has all of the powers of the country in hand and this is impossible without a central power ${ }^{14}$.Democrats emphasized that this centrality should be created through national institutes and should be in the hands of those elected by the nation that is the parliament representatives. (parliamentary branch statement, Safar 1950) accordingly they believed that the parliament should be the reflection of the center of all state power affairs and under the parliamentary principles hold these powers always in control and keep the administrative power completely under the control. (ibid) Democrat party called for centrality and parliamentary system by the condition that the majority of the people participate in it. According to this party the country should be controlled on the basis of democratic principles and any law passed in the parliament should provide the interest of the toilers, villagers, and the shopkeepers and unions. (Parliament negotiations, $7^{\text {th }}$ of Rabiolavval 1950) The foreign policy of this party consisted of persistence policy and not losing the rights of the country, not succumbing to the illegal demands and eliminating the encroachments of foreign powers by the people. Democrats believed that if the country because of the lack of required facilities a policy should be applied that at least the country should not be readily succumbed to others (Irane-no, $17^{\text {th }}$ of Rabiolavval 1950,1$)$ Democrat party was especially concerned about the imperialistic policies of Russia and England in Iran and assisting the internal alliances (democrat sect statement, $5^{\text {th }}$ of Zelhaje 1949) party press in Tehran and other towns spent a considerable part of the package to the movements of these countries especially Russia ${ }^{15}$. Democrat tactic for saving the state independence was to establish a $<$ national rescue committee $>$ with the presence of all active political parties. The plan of establishing this committee in via a private resolution was communicated to the members (private resolution, $23^{\text {rd }}$ of Zelhaje 1949) and was published completely in number 8 of the Irane-no paper ${ }^{16}$.

\section{Democrat Party in Practice}

Democrat party despite having organizational programs and regular organization was not successful in fulfilling the party goals as it was expected. The lack of success of democrats in this respect originated from two main issues. One was the political and religious atmosphere and the dominant economic relation in Iran along with lack of apposite understanding of the conditions and the incongruent combination of leaders and other constituting elements of the party. Parts of the programs of this party given the current conditions of the society did not have administrative possibility. For instance, the land policy of the party which was in fact the most developed policy of the democrats was confronted with lots of serious obstacles to be practiced. Following this policy contrasted the party with several power holders in Iran. From the late $16^{\text {th }}$ century afterwards because of 
the combination of economy of Iran in the economy of the world land was considered as an important source of producing monetary products for apposite profitability and export. This led some of the court members and the great tradesmen and local rulers and masters to land ownership. (Issawi 1971, 55) These social and political powers had a lot of influence and power in parliament and government and some of them were considered as the leaders of the constitutionalism. Naturally the democrats who had a small share of the power structure did not have the administrative power of administering the land distribution project to the farmers. On the other hand while these programs and plans of the democrat party were influenced by socialism but its leaders did not have the same understanding of this thought. Rasulzade, Pilusian and Terhakupian knew the theoretical principles of socialism and believed in it in practice. And it was them who codified the organizational party goals and moved it towards the left. Heidarkhanamogli also believed in the same way but he was mostly a practical type of person rather than a theoretician ideologue ${ }^{17}$. Others in the party were not the same as the aforementioned people in terms of the familiarity with the principles of the democrat social party and only considered it as a developed thought ${ }^{18}$. In addition to that in the organizational combination of the Democratic Party there were different types of intellectual ideologies. In this party the members also believed in social democrat and revolutionary and even active liberalism. (Admit 2009, 139) Democrat party which had set democratic activities as its priority goals because of its incongruent combination sometimes diverted into revolutionary mode. And this had a considerable role in weakening the party and as a result reduced the administrative power of the party. A significant instance of it is the terror of Ayatollah Behbahani which led to the exile of Tagizade, death of Ali Muhammad Tarbiyat, pressure on the party and the fall of its value among the people. (Kasravi, 2007, 131) such extremisms confronted not only the clergy men and the public against the party but also the modest reformists. But the leaders of the party were also responsible of this behavior. They despite their strategy had a glance at military method. In some of the private resolutions of the central committee the party invited provincial committees to the military method and military missions and the training the use of arms to them. (private resolution $2^{\text {nd }}$ of Zelhaje 1949, article 8) certainly such contradictions in policy making from the leaders led the lower level members into revolutionary stage. The behavior of the democrats in the parliament was another reason in addition. They rather than developing their organizational goals were engaged in group contradictions and confrontation with ETEDALIYUN. In spite of that it should not be forgotten that democrats established the first political parliamentary system in Iran and encouraged the parliament for party activities. Party competitions in parliament in spite of all of its deficiencies and weaknesses were the starting point to practice democracy in Iran.

\section{Ideological Attempts}

The other part of democrat party activities was directed towards spreading ideological thoughts. Rasulzade and Tabriz group socialists who had found an apposite resort took advantage of the provided situation. Irane-no which was published at an appositecredit provided them with an opportunity to advertise Marxism and Socialism. Quickly the articles about Marxism were published in Irane-no ${ }^{20}$. It was the first time that this ideology was advertised in Iranian society at such a level.

The first text that was about socialism in Iran was an article that the $<\operatorname{Iran}>$ paper quoted from the Akhtar paper published in Istanbul in 1297 lunar (1880). (Iran, 26 of Rabiolavval, 1297,3) But this article has a critical view and not an advertising position and provided inaccurate and faulty information for its limited readers. Then at the beginning of constitutionalism intellectuals such as TalbofTabrizi and Aga khan Kermani wrote about socialism in their writings. In addition to limitedness of such writings even the audiences of them were low-educated people of Iranian society, their writers did not have thorough familiarity with socialism and did not believe in absolute obedience of it. The first attempts to familiarize the Iranians with socialism principles go back to the formation of organizations and democrat social groups in the country. The activities of the two parties of Henchak and Dashnak consisted of doing advertisement among the Iranian Armenians and even non-Armenians. (Khosropanah, 2009, 14) And also the Iranian group of the Henchak party in Anzali published a pamphlet by the purpose of spreading socialist beliefs in their activity region. (Yagikiann.d. on the cover) The majority of the Tabriz group published the social democrat paper in this city. (Chalangarian to Kaotski June, 1910) In addition to them GrigoryOrjonikidze who had come from the Baku committee of Russian worker social democrat to Iran established a community in Rasht which advertised socialist thoughts and translated part of the (communism party manifest) into Persian (Gufurov, and Kim 1978, 308) But non of these activities in terms of expansion and continuity were not comparable with the article published in Irane-no. The advertisement activities of the party theorists were not limited to these articles. Rasulzade wrote a comprehensive critical essay of ETEDALIYUN that more than two thirds of it was about socialism and Marxism and the mental branches originating from it. (Rasulzade 1949, 3-28) The study of this essay was repeatedly recommended to the readers in the paper for the same reason the ideological measures of the democrats founded the first substrates of the socialist literature and 
discourse in Iran.

\section{The End of Democrat Party}

By the end of the second national parliament period the democrat party became weaker. Before that Tagizade and Rasulzade were forced to leave Iran. After the shut down of the parliament, the government and Naiebossaltaemalekexiled other heads of the party to Qom and in this way the activities of the party to a large extent decreased. (Bahar, 2009, 12) But when Ahmad shah became mature and did coronation and Naserolmalek fell down from power and there was a chance for the democrat party to restart activities and take part at third parliament. Democrat party succeeded to obtain the majority of the third parliament. (union1992, 113) This party in spite of the success at the election was never able to obtain the early congruity again. The third party operation was co-occurred the First World War and under its influence became annulled. By the start of the First World War Iranian state announced its neutrality to the aggressive states but these states without considering the neutrality of Iran occupied the Northern, Southern and Western parts of Iran. At this time of the democrat party members and others (National defense committee) was established in Qom. The rush of the Russian forces to Qom made the national defense committee to migrate to Kermanshah by the enjoinment of Nezamossaltane to them the <national state $>$ was established. Finally at Khanegin border when the national state was forced to withdraw in front of the Russian forces two parties of democrats and ETEDALIYUN decided to cancel their parties and become united. (Dolatabadi, 1983, 297-368) SoleimanmirzaEskandari was also the most influential member of the party was arrested by the English and exiled to England (Shakeri, 2005, 275) later some members of the party tried to revive the party again and to this end a committee was created (democrat establishment) but this fact was opposed by some other democrats who were referred to as <anti-establishment> and was not concluded. (Bahar, 2009, 27) After the Reza khan coup and in fourth parliament some of the democrats under the leadership of SoleimanMirzaEskanadri established the $<$ socialist $>$ party.

\section{Conclusion}

The performance of democrat party at two fields of party organization and the administration of organizational purposes had different results. Democrats in an action to organize the party have left a relatively positive report of them. By considering a codified program in a short period of time they were able to create the first type of coordinated party establishment in Iran. The success of the democrats originates from the previous experience of party practice. The firs core which was in operation under the name of temporary center committee which started the establishment of the party was composed of people that some in terms of theory and some in terms of practice were considered as experts. Such backgrounds led the democrats to make use of regular establishment programs in addition to activating their parliamentary branch in the parliament arrange branches and headquarters in Tehran and other cities properly. But the organizational coordination of the democrat party under the influence of the inside and outside organization factors after some time wavered. Aggressive reaction to rivals and the internal and external pressures facilitated the fall $\mathrm{f}$ the influential activists of the party. Terror of the Mirza Hassan khan aminolmolk not only led to the exclusion and exile of the party leaders but incited extreme responses in parliament and afterwards and reduced the social and political value of the party. Very soon the party was confronted with extreme attacks and had to withdraw from its organizational programs and therefore the democrat party was not successful as expect in terms of the party goals. This party which was following the anti-Russian policy by the start of the First World War by the alliance of the England and the Tsar the party had to confront both of them. The inclination of the democrats to Germany at this time and the victory of the allies and the occupation of Iran by them finally led to the collapse of the democrat party.

\section{Subscripts}

1) Development of industries, especially the development of Baku oil industry provided more opportunities for the workers in this region. In 1859 in Surakhani near Baku the largest Russian oil refinery was established and in addition to that in peninsula of Abshuran tens of oil industry institutes were established. In 1893 in this industry 700 workers were working and $11 \%$ of them were Iranian. In 1993 the number of the workers reached 23500 worker and 22/2 percent of them were Iranian.

2) The most important centers of Henchak and Dashnak activities were the cities of Azerbaijan and Gilan. They in addition to Tabriz, Khoi, Salmas, they were active in Rasht and Anzali. The programs of these two parties emphasized on the advertisement among the Armenians but its activists by finding the situation apposite started advertisement among non-Armenians. Its example is the establishment of Iranian group of Henchak group in Anzali consisting of Muslim youths.

3) But at the period of Stalinist history writing the original innovation of establishing Hemmat was referred to Stalin himself. For the fist time Bagerof one of the relatives of Stalin presented this theory. Later Ivanof and 
Buramensky from Stalinist historians approved it. Hemmat has a significant role in attracting the Muslim community of the region to revolutionary and working activities and organizing them. Naturally assigning the establishment of Hemmat organization Stalin included such impacts on worker movement and socialism of the region. Muslims first considered socialism as slogan which is put forward by the unbelievers against the capitalism system. As Souitokhsku states they showed that they have no immunity against those of the same creed.

4) Narimanof was an Azerbaijani physician and a citizen of Russia. His cooperation with activist Iranians in trans-Caucasus $t$ establish EJTEMAIYUNAMIYUN originates from his intellectual principles. He was originally Iranian and attended to the elimination of problems and issues of immigrant Iranians. EJTEMAIYUNAMIYUN was established $\mathrm{b}$ the purpose of assisting Iranian immigrants and mainly acted in this respect.

5) Tabriz community which had brought under control all of the Azerbaijan by establishing local committees in Tabriz and other towns to solve the problems of the people, following their complaints controlling the price of the basic goods and establishing new schools acted the same as a state organ. This community had a considerable role in organizing the Tabriz revolution against Muhammad Ali Shah

6) In this penalty statement it is stated: <at this time that in accord of the interest of the followers the services of the EJTEMAIYUNhad fruited the justice and constitutionalism was established in Iran some of the members in support of their fellow members established partying!! And since these activities caused stoppage in the process of independence of Iran and also the beliefs of the constitutionalists therefore by the sacred sect for the time being the branches of the MojahedEJTEMAIYUNAMIYUN was confiscated from Tehran and other provinces and the reestablishment was suspended until some unbiased members are selected.

7) Irane-no paper in the explanation of this article wrote: <as long as there is no complete certainty of diversion the extremism between the left wing liberals would give a superior power to the right wing which is harmful for the liberalism. Then the central committee needs to determine peacefully and cordially its interactions with sects which are left-oriented.>

8) The first edition of the Mujahed in Tabris was published in 1946 September of 1907. 22 editions were published from Mujahed of Tabriz and its last edition goes back to 1946/1907

9) Refer to the goal of the Irane-no paper second year, number 1, 1947/1910

10) Rasulzadebefore this had the editorial of press such as $<$ Hemmat $><$ Takamol $>$ and cooperated with the papers $<$ Davat $>-<$ Guch $>$, $<$ Yoldash $><$ Ershad $>$ and $<$ Taragi $>$

11) In addition to the programs byEJTEMAIYUNAMIYUN either at Baku program and or Mashhad passed program this issue was emphasized. Active EJTEMAIYUN of Tabriz had suggested the land division of farmers and the correction of land ownership system to the provincial community of this city which was not attended.

12) Taghizade in this respect says that the code of conduct of democrats seemed a bit extreme compared to that time and had extremism to get freedom such as the gradual delivery of the land to the vassal and the differentiation of spiritual power from political was part of the announced code of conduct

13) This resolution in addition to the emphasis on the fact that the members should $<$ the members should follow and observe the general religious beliefs and religious ceremonies and verbally and practically respect so that no excuse is give to the clergy men> States the loss of belief of the clergymen and the harms of religious tyranny.

14) Refer to rhetoric by Sheyk Muhammad Khiyabani, $23^{\text {rd }}$ of 1950 at national counsel parliament

15) Democrat party in spite of open anti-imperialism directed most of its criticisms against the Russian government and showed more softness against England

16) Refer to numbers 21 afterwards of the Irane-no paper in addition to the establishment of national defense committee articles in the justification of it

17) Hedarkhan before knowing the theoretic issues attended the organization of the party. At the time of activity in branches of EJTEMAIYUNAMIYUN acted the same and had apposite capabilities in this respect

18) Written works of people such as Soleimanzade and SoleimanMirzaEskandar at this time show that they did not have theoretic familiarity with socialisms and only considered it as a developed idea. After some time Tagizade departed from this ideology and but Eskandari established a party in this respect.

19) The parliamentary branch of the party was first managed by Tagizade but after the announcement of the judgment on his political corruption and the necessity of preventing his activities in parliament by Ayatollah Mazandarani and AkhundKhorsasniwas forced to take a compulsory leave from parliament and left Tehran for 
Tabriz. He was later forced to leave Iran

20) Refer to Irane-no paper second year numbers $16,44,49,54,57,58,59,62,64$. worker strikes news were also reported in significant numbers of this paper.

\section{References}

A democrat person. (1949). (democracy principle thesis) Tehran Tus publication Tehran documents archive.

Abrahimiyan, Y. (1998). Iran between two revolutions translation by Ahmad golmohammadi and Ebrahim Fattahi (10th ed.). Tehran, Nei publication.

Adamiyyat, F. (2009). Social Democratic thought in the revolution of constitutionalist of Iran (1st ed.). Gostarde publication.

Afanasiyan, S. (1991). Armenia Azerbaijan Georgia. translated by Abdoreza Hushang Mahdavi, Tehran, Mihan publication.

Afari, Z. (2000). Iran's constitutionalist revolution. translated by Reza Rezaian, Tehran Bistoon publication.

Artoniyan, G. C. (2006). Iranian revolution and Bolsheviks of Transcaucasia translated by Muhammad Nayeb poor (1st ed.). Tehran, Humanitarian studies research and development center.

Bahar, M. (2009). brief history of political parties of Iran. Tehran Amirkabir publication.

Browne, E. G. (1910). The Pesian Revolution of 1905- 1909. Cambridge.

Dolatabadi Yahya. (1983). Hayat Yahya third v (4th ed.). Tehran, Attar and Ferdosi publications.

Ebrahimof, T. A. (1981). the appearance of Communism party of Iran. translated by Radnia first edition, Tehran, Gunesh publication.

Etehadiye, M. (1991). Political parties at the third parliament (1st ed.). Tehran Iran history publication.

Gafurov, B. G., \& Kim, G. F. (1978). Lenin and National Liberation in the East, Moscow.

Issawi, C. P. (1971). The economic history of Iran. Chicago.

Kasravi, A. (1980). Iran constitutionalist history (Vol. 2, 15th ed.). Tehran, Amirkabir publication.

Kazemzadeh, F. (1951). The Struggle for Transcaucasia (1917- 1921). Oxford.

Khosropanah, M. H. (2009). the role of Armenia in social democrat of Iran (1st ed.). Tehran, PardisDanesh and Nashr publication.

Malekzade Mahdi. (1984). constitutionalist revolution history of Iran (Vol. 6, 2nd ed.). Tehran scientific publication.

N. D. (1881). Armenian revolutionary federation (Dawsnatkstin) (1st ed.). Tehran the fans of Armenian revolutionary federation (Potril).

N. D. (1946). a page of the constitutionalist Iran history Heidar khan amogli, Yadegar, third year fifth number, pp61-80.

Padmagariyan, A. (1983). Armenia social and political history (Armenakan, Dashnktowstiun, Honchakian) (1st ed.). Tehran, Pad cultural organization.

Rafie, M. (1983). association (Azerbaijan provincial association organ). Tehran, Iran history publication.

Ravasani Shapoor. (1984). Mirza Khan Jangali revolution and the first council of republicans in Iran (1st ed.). Tehran Chappakhsh.

Reza zade Malek Rahim. (n.d). Heidar khan Amuogli (revolution abstract) firdt edition bija, Ruzbeh publication.

Shakery Khosro. (2005). economic and social background of constitutionalist movement and democratic social (1st ed.). Tehran Akhtaran publication.

Shuster, W. M. (1913). The Strangling of Persia. London.

Switokhski Tadius. (2002). Russia Azerbaijan (national identity in a Muslim society). translated by KazemFiruzamnd first edition Tehran Shadgan publication.

Taghizade Seyyed Hassan. (1957). the substrate of constitutionalist revolution (three lectures) (1st ed.). Tehran, Gam publications.

Talbof, A. (1924). Masalekol Mohsenin Gahere, n.d. 
Trotsky, L. (1973). 1905, Middlesex: Penguin Books.

Yagikian Grigor. (n.d). what do social democrat wants? social democrat group (Henchakian) Anzali branch Iranina group Rasht OrvatolVosga publication.

\section{Notes}

$<$ Mojahedin organization statute $>$ (10 of September 1907) Shakeri (1979) labor movement history documents, social democratic communism of Iran, $6^{\text {th }} \mathrm{V}$. Tehran, Elm publication pp. 16-24.

$<$ Entebah name of the EJTEMAIYUN-AMIYUN> (January 1910) IRANE-NO first year N122 $20^{\text {th }}$ of Muharram 1949 February 1910.

$<$ democrat party of Iran parliamentary branch statement> (1950) Irane no second year No. 119, 120, 17 and 16 1950/1911, pp1-2.

$<$ democrat party of Iran statement> 1949, Irane no second year No. 41 Thursday of Zelhaje 1949) December 1910,p.1.

$<$ democrat party of Iran temporary center ten months activity report>n.d.Afshar by 1980 newly found documents on constitutionalism and Tagizade Tehran, Javidan publication p.366.

$<$ Tabriz group meeting proceedings $>\left(16^{\text {th }}\right.$ of October 1908) n.d. 1979 historical documents sixth volume pp. 50-53.

$<$ democrat party of Iran private resolutions $>3$ oth of Zelgade 1948), 23 of Zelgade 1948) and $9^{\text {th }}$ of Rabiollaval 1949) Islamic counsel library.

$<$ democrat party of Iran political sect statute and rules, Amiyun) (1328 lunar) Tehran state publication Iran's nationa documents and library archive.

$<$ Mujahedin population code of conduct $>10^{\text {th }}$ of September 1907) Shakeri, (n.d.) historic documents first edition, second publication Tehran Elm publication pp.45-46.

$<$ Code of conduct of democrat party of Iran Amiyun $>1328$ lunar) Tabriz, Omid publication Islamic Parliament library.

$<$ democrat party of Iran parliamentary branch statement> (n.d.) Afshar (ibid) pp.350-352.

and also the leeters by Karkhaniayn to Polkhanof (15 of September 1905), Chalangarian to Kaotsky (16 of January 1908), Terhakupian to Polkhanof ( $3^{\text {rd }}$ of December 1908) and Chalangarian to Kaotski $\left(27^{\text {th }}\right.$ of June 1910) in Khosropanah (2009) the role of Armenians in social democrat of Iran pp.77-114 and Parviz to Taghizade, (18 ${ }^{\text {th }}$ of Shavval 1949) ibid, in order of lesson 328 and pp.251-262.

and the materials from Iranian papers, Irane-no, Mojahed, Nasimeshomal, Nobahar, official newspaper of the country, Majlis negotiations.

\section{Copyrights}

Copyright for this article is retained by the author(s), with first publication rights granted to the journal.

This is an open-access article distributed under the terms and conditions of the Creative Commons Attribution license (http://creativecommons.org/licenses/by/3.0/). 